\title{
anatomy
}

Original Article

www.anatomy.org.tr

Received: October 13, 2016; Accepted: December 13, 2016

doi:10.2399/ana.16.039

\section{Sex determination from the radiographic measurements of calcaneus*}

\author{
Muhammet Bora Uzuner ${ }^{1}$, Ferhat Geneci ${ }^{1}$, Mert Ocak ${ }^{1}$, Pınar Bayram² ${ }^{2}$ İbrahim Tanzer Sancak ${ }^{3}$, \\ Anıl Dolgun ${ }^{4}$, Mustafa Fevzi Sargon ${ }^{1}$ \\ ${ }^{1}$ Department of Anatomy, School of Medicine, Hacettepe University, Ankara, Turkey \\ ${ }^{2}$ Department of Histology, School of Medicine, Ankara University, Ankara, Turkey \\ ${ }^{3}$ TOBB University of Economics and Technology Hospital, Department of Radiology, Ankara, Turkey \\ ${ }^{4}$ Department of Biostatistics, School of Medicine, Hacettepe University, Ankara, Turkey
}

\begin{abstract}
Objectives: The main reason why the calcaneus is chosen for the sex determination is due to its solid structure and resistance to postmortem changes. The comparison of calcanei in radiographies ensures the determination of the sex of corpses whose sex is unknown. A number of skeletons that have been studied as part of the sex determination studies, as well as the variability extents of the male and female samples in the physical and forensic anthropologies which deal with the analysis of the past and present biodiversity, provide information for the observation of data like age, height and sex that are essential for identification.

Methods: In this study, we used the radiographies of patients in the Radiology Department of TOBB University of Economics and Technology Hospital. A total of 143 individuals (including 66 male and 77 female patients) whose calcanei were anatomically normal were involved in the study. The participating individuals were divided into three groups: Group 1 consisted of individuals born in and before 1970, Group 2 consisted of individuals born between 1971 and 1985, and Group 3 consisted of individuals born in and after 1986. Sex distribution was similar in each of the three age groups. Metric and non-metric methods were used in the process of identification held with the aim of sex distinction. Metric measurements were made for eight parameters of the calcaneus, e.g. maximum width, body width, maximum length, minimum length, height of the facies articularis cuboidea, tuber angle, front angle and the tuber plantar angle.

Results: The maximum, minimum and average values of the conducted measurements were obtained. In each of the age groups, differences were observed between the metric lengths of the female and male parameters. Groups 1 and 2 showed similarities in the angular (alpha, beta, sigma) lengths and Group 3 showed similar values in alpha and sigma angles. A statistically significant difference was observed in the beta angle of Group 3. When all of the measurements of the three groups were compared, the maximum height, the minimum height and alpha angle showed similarities, whereas in other parameters a statistically significant difference was observed.
\end{abstract}

Conclusion: This study reveals the importance of calcaneus in the sex determination and suggests that it can be used as an alternative method in the forensic anthropology and forensic sciences.

Keywords: anatomy; calcaneus; forensic anthropology; radiography; sex determination

Anatomy 2016;10(3):200-204 @2016 Turkish Society of Anatomy and Clinical Anatomy (TSACA)

\section{Introduction}

While determining the basic data such as age, height and sex in physical and forensic anthropology, the differences in calcaneus in between males and females are important. ${ }^{[1,2]}$ In cases with the presence of the majority of skele- ton's parts, one can say that the individual's sex will be correctly determined with $90 \%$ of accuracy. ${ }^{[3]}$

Different parts of skeletons have been analysed in the studies of sex determination. Based on Washburn's studies of sex determination in different societies, the most successful results were achieved using the pelvis. ${ }^{[4]}$

*This study has been presented as an oral presentation at the XVII National Anatomy Congress in Eskisebir, Turkey in 2016. 
Meanwhile, according to Şahiner and Yalçın's reference to Scheuer, sex can be determined with $80 \%$ confidence using the cranium; with $90 \%$ confidence using the head and mandible, and with $80 \%$ confidence using the pelvis. ${ }^{[5]}$

Sex determination can be made by the radiographic measurements of the calcaneus. ${ }^{[6]}$ This method ensures an alternative facility to possible problems arising from the post-mortem changes in the skeleton. The relevance of calcaneus in sex determination was asserted by a number of authors. ${ }^{[-9]}$ The main reason why the calcaneus is chosen for the determination of sex is related to its solid structure and its resistance to post-mortem changes. ${ }^{[6]}$

\section{Materials and Methods}

In this study, radiographs were obtained from the Department of Radiology of TOBB University of Economics and Technology Hospital. The calcanei of 66 male and 77 females (a total of 143 individuals), anatomically normal in every aspect, were used (Ethics committee approval numbered GO16 / 68 with meeting number 2016/08).

The radiographs were divided into three groups. Group 1 contained individuals born in and before 1970 $(\mathrm{n}=43)$, Group 2 consisted of patients born in between 1971-1985 ( $\mathrm{n}=40)$, and Group 3 included patients born in 1986 and afterwards $(\mathrm{n}=60)$. Grouping was done because of the foot's anatomy and changes in bone development in different age groups. The bony mass reaches to its maximum density in the ages of 30-35. After this age interval, the bone turnover results in the loss of bone mass. ${ }^{[10]}$ Because of this, individuals younger than 30 were included in a separate group, Group 3. Group 1 included people older than 45 years old due to the possibility of osteoporosis after the age of $45 .{ }^{[1]}$ In the identification process used for the sex determination, metric and non-metric methods were used. In this study, the metric methods were chosen.

After determining the following eight parameters from the latero-lateral radiographies of calcaneus, we conducted the metric measurements with the eFlim program which is appropriate to the PACS system that is used in the TOBB University of Economics and Technology Hospital (Figure 1).

Maximum width (a-g): The distance in between the most posterior point of calcaneus and the highest point of the height of facies articularis cuboidea.

Body width (b-g): The distance in between the most posterior point of calcaneus and lowest point of the height of facies articularis cuboidea.

Maximum length (e-f): The distance in between the most superior and most inferior points of the calcaneus.
Minimum length (c-d): The distance in between the deepest points of the superior and inferior surfaces calcaneus.

The height of facies articularis cuboidea $(\mathbf{a}-\mathbf{b})$ : The distance in between the highest and lowest points of facies articularis cuboidea.

Tuber angle ( $\alpha$ ): The angle in between the line drawn from uppermost point of facies articularis cuboidea to most anterior point of calcaneus' superior surface and the line drawn from the most anterior point of calcaneus' superior surface to the most posterior point of this surface (Figure 2).

Anterior angle ( $\beta)$ : The angle in between the line drawn from the lowest point of facies articularis cuboidea to most posterior point of calcaneus's superior surface and the line drawn from the lowest point facies articularis cuboidea to most posterior point of the inferior surface of calcaneus (Figure 2).

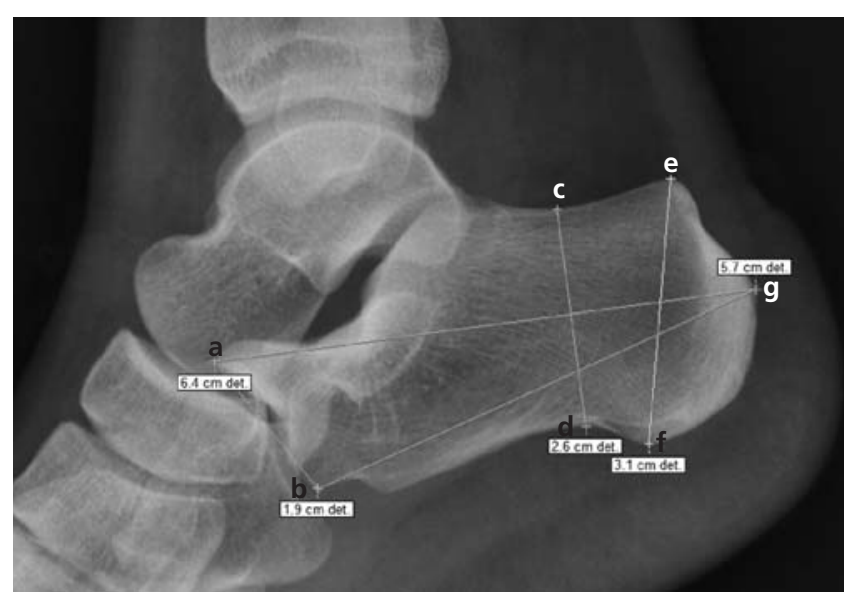

Figure 1. Measurements for maximum width $(a-g)$, body width $(b-g)$, maximum length (e-f), minimum length $(c-d)$, and height of facies articularis cuboidea $(a-b)$.

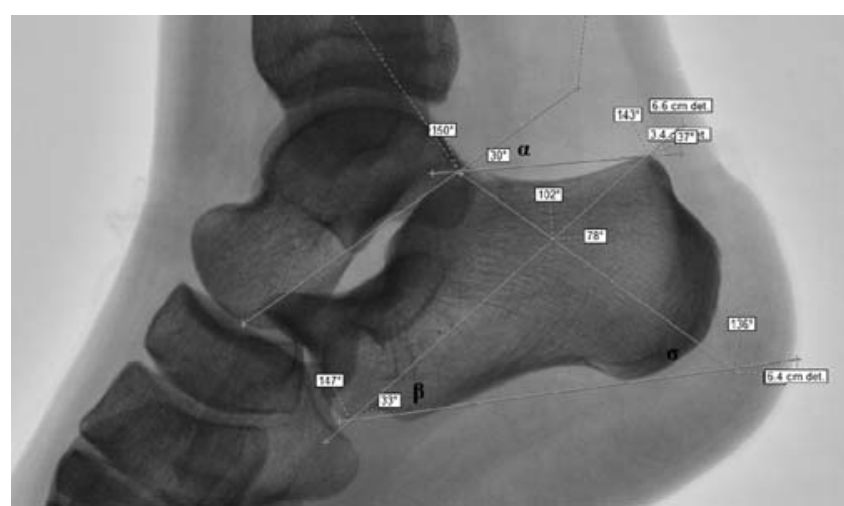

Figure 2. Tuber angle $(\boldsymbol{\alpha})$, anterior angle $(\boldsymbol{\beta})$ and tuber plantare angle $(\boldsymbol{\Sigma})$. 
Tuber plantare angle $(\Sigma)$ : The angle in between the line drawn from the most posterior point of calcaneus to the line of most inferior point of calcaneus and the line drawn from the intersection of the previous parameters to most posterior point of superior surface of calcaneus (Figure 2).

\section{Statistical analysis}

Mean \pm standard deviation (SD) and median values were used to describe the quantitative variables. Also, frequency and percentages were given for the nominal data. Normality assumption was checked by Shapiro Wilk's test. Since data did not conform to normal distribution, non-parametric statistical tests were used. The distribution of qualitative variables among study groups was analyzed by chi-square test. Within each age group, MannWhitney $\mathrm{U}$ test was used to compare females and males in terms quantitative variables. Kruskal-Wallis test (with the Conover-Dunn multiple comparison technique) was used to compare quantitative variables among age groups. For all analyses, IBM SPSS Statistics for Windows (Version 21.0, Armonk, NY) was used and statistical significance was set at $\mathrm{p}<0.05$.

\section{Results}

Among males $24.2 \%$ of $(16 / 66)$ were in Group 1, 30.3\% $(20 / 66)$ were in Group 2 and $45.5 \%(30 / 60)$ of were in Group 3. Among females, $35.1 \%$ of $(27 / 77)$ were in the Group 1, 26\% (20/77) were in Group 2, and 39\% $(30 / 77)$ of were in Group 3. The sexes in the age groups were observed to be similar ( $\mathrm{p}=0.372$ ). Mean, standard deviation and median values for each parameter among age groups are shown in Table 1 . In each of the age groups, the defining statistics of each sex were separately defined (Table 2 ). The statistically significant differ- ence according to sex was observed in the parameters a$\mathrm{g}, \mathrm{b}-\mathrm{g}, \mathrm{b}-\mathrm{a}, \mathrm{e}-\mathrm{f}, \mathrm{c}-\mathrm{d}$ for all parameters $(\mathrm{p}<0.001)$. The difference between the age groups was determined in a$\mathrm{g}(\mathrm{p}=0.012), \mathrm{b}-\mathrm{g}(\mathrm{p}=0.014), \mathrm{b}-\mathrm{a}(\mathrm{p}=0.025)$, tuber angle $(\alpha)(p=0.002)$, and anterior angle $(\beta)(p=0.036)$ measurements.

In the first group, significant statistical difference was observed in all of the parameters $(\mathrm{p}<0.05)$ except for the tuber angle $(\alpha)(p=0.17)$, the anterior angle $(\beta)(p=0.343)$ and tuber plantare angle $\left(\sum\right)(\mathrm{p}=0.92)$ (Table 2). In the second group, statistically significant difference was observed in all of the parameters $(\mathrm{p}<0.05)$ except for the tuber plantare angle $(\alpha)(\mathrm{p}=0.184)$, the anterior angle $(\beta)$ $(\mathrm{p}=0.673)$ and tuber plantare angle $\left(\sum\right)(\mathrm{p}=0.585)$ (Table $2)$. In the third group, statistically significant difference was observed in all of the parameters $(\mathrm{p}<0.05)$ except for the tuber angle $(\alpha)(p=0.722)$, and the tuber plantare angle $\left(\sum\right)(\mathrm{p}=0.051)($ Table 2$)$.

\section{Discussion}

In females and males, Riepert et al. ${ }^{[6]}$ found the mean value of tuber angle $33.8^{\circ}$ and $34.7^{\circ}$ mean value of the anterior angle $40.1^{\circ}$ and $41.2^{\circ}$ and mean value of tuber plantare $73^{\circ}$ and $72^{\circ}$, respectively. In our study, the mean value of tuber angle was $33.52^{\circ}$ and $35.14^{\circ}$, mean value of anterior angle was $38.96^{\circ}$ and $40.32^{\circ}$ and mean value of tuber plantare was $46.03^{\circ}$ and $46.59^{\circ}$, respectively. In the study of Riepert et al. ${ }^{[6]}$ there was obviously a greater difference between males and females in the linear measurements than in angles. The authors found the male calcaneus significantly to be larger than the females. However, there was no difference in their proportions. In our study, the mean value of tuber plantare was found to be smaller than Riepert's research. ${ }^{[6]}$

Table 1

Descriptive statistics of parameters among age groups [mean \pm SD (median)].

\begin{tabular}{lcccc}
\hline Variables & Group $\mathbf{1}(\mathbf{n}=\mathbf{4 3})$ & Group $\mathbf{2}(\mathbf{n}=\mathbf{4 0})$ & Group $\mathbf{3}(\mathbf{n}=\mathbf{6 0})$ & $\mathbf{p}$ \\
\hline Age & $55.93 \pm 8.19(54)$ & $37.72 \pm 4.36(38)$ & $22.4 \pm 4.69(22.5)$ & - \\
a-g & $7.55 \pm 0.96(7.7)$ & $8.185 \pm 0.9(8.1)^{*}$ & $8.012 \pm 0.97(8.05)$ & 0.012 \\
b-g & $6.93 \pm 0.87(7)$ & $7.49 \pm 0.93(7.6)^{*}$ & $7.29 \pm 0.91(7.45)$ & 0.014 \\
b-a & $2.3 \pm 0.35(2.3)$ & $2.49 \pm 0.33(2.5)^{\dagger}$ & $2.31 \pm 0.35(2.3)$ & 0.025 \\
e-f & $4.36 \pm 0.71(4.5)$ & $4.58 \pm 0.59(4.65)$ & $4.41 \pm 0.68(4.5)$ & 0.396 \\
c-d & $3.62 \pm 0.53(3.7)$ & $3.75 \pm 0.48(3.7)$ & $3.77 \pm 0.60(3.8)$ & 0.463 \\
Tuber angle $(\alpha)$ & $32.81 \pm 5.39(32)^{\dagger}$ & $33.025 \pm 6.35(33)^{\dagger}$ & $36.13 \pm 5.42(37)$ & 0.002 \\
Anterior angle $(\beta)$ & $41.09 \pm 5.39(41)^{\dagger}$ & $39.35 \pm 4.07(39)$ & $38.67 \pm 357(39)$ & 0.036 \\
Tuber plantare angle $(\Sigma)$ & $46.86 \pm 3.52(47)$ & $45.65 \pm 3.75(46.5)$ & $46.3 \pm 2.77(46)$ & 0.339 \\
\hline
\end{tabular}

*Significantly different from Group 3 ( $p<0.05)$; tsignificantly different from the Group $1(p<0.05)$ 
Table 2

Descriptive statistics of parameters among gender and within each age group [mean \pm SD (median)].

\begin{tabular}{|c|c|c|c|c|}
\hline Parameters & Groups & $\begin{array}{c}\text { Males }(n=16) \\
\text { Mean } \pm \text { SD (Median) }\end{array}$ & $\begin{array}{c}\text { Females }(n=27) \\
\text { Mean } \pm \text { SD (Median) }\end{array}$ & $p$ \\
\hline \multirow[t]{3}{*}{$a-g$} & Group 1 & $8.25 ; 0.69(8.3)$ & $7.13 ; 0.84$ (7.3) & $<0.001$ \\
\hline & Group 2 & $8.82 ; 0.57(8.8)$ & $7.55 ; 0.69(7.65)$ & $<0.001$ \\
\hline & Group 3 & $8.52 ; 0.81(8.7)$ & $7.51 ; 0.83(7.65)$ & $<0.001$ \\
\hline \multirow[t]{3}{*}{$b-g$} & Group 1 & $7.6 ; 0.63(7.5)$ & $6.53 ; 0.75(6.8)$ & $<0.001$ \\
\hline & Group 2 & $8.095 ; 0.65$ (8) & $6.88 ; 0.76$ (6.95) & $<0.001$ \\
\hline & Group 3 & $7.75 ; 0.7(7.75)$ & $6.85 ; 0.87(7)$ & $<0.001$ \\
\hline \multirow[t]{3}{*}{$b-a$} & Group 1 & $2.49 ; 0.26(2.45)$ & $2.19 ; 0.34(2.2)$ & 0.004 \\
\hline & Group 2 & $2.67 ; 0.26(2.65)$ & $2.315 ; 0.28(2.3)$ & $<0.001$ \\
\hline & Group 3 & $2.47 ; 0.3(2.5)$ & $2.15 ; 0.31(2.15)$ & $<0.001$ \\
\hline \multirow[t]{3}{*}{$e-f$} & Group 1 & $4.85 ; 0.48$ (4.95) & $4.062 ; 0.65(4.1)$ & $<0.001$ \\
\hline & Group 2 & $4.985 ; 0.38(4.9)$ & $4.17 ; 0.46(4.2)$ & $<0.001$ \\
\hline & Group 3 & $4.84 ; 0.52(4.9)$ & $3.98 ; 0.52(4)$ & $<0.001$ \\
\hline \multirow[t]{3}{*}{$c-d$} & Group 1 & $3.95 ; 0.41(4.1)$ & $3.42 ; 0.50(3.4)$ & 0.001 \\
\hline & Group 2 & $3.97 ; 0.43(4)$ & $3.52 ; 0.40(3.55)$ & 0.001 \\
\hline & Group 3 & $4.01 ; 0.51(4)$ & $3.52 ; 0.58(3.45)$ & 0.001 \\
\hline \multirow[t]{3}{*}{ Tuber angle $(\alpha)$} & Group 1 & $33.93 ; 5.82(35.5)$ & $32.14 ; 5.11(31)$ & 0.17 \\
\hline & Group 2 & $34.7 ; 7.18(33.5)$ & $31.35 ; 5.03$ (32.5) & 0.184 \\
\hline & Group 3 & $36.06 ; 6.07$ (37) & $36.2 ; 4.76(36.5)$ & 0.722 \\
\hline \multirow[t]{3}{*}{ Anterior angle $(\beta)$} & Group 1 & $42.56 ; 7.08(42)$ & $40.22 ; 3.99(41)$ & 0.343 \\
\hline & Group 2 & $39.05 ; 4.23$ (38.5) & $39.65 ; 3.97$ (40) & 0.673 \\
\hline & Group 3 & $39.96 ; 2.90$ (39.5) & $37.36 ; 3.74$ (37) & 0.003 \\
\hline \multirow[t]{3}{*}{ Tuber plantare angle $(\Sigma)$} & Group 1 & $3.56 ; 46.75$ (46.5) & $46.92 ; 3.55(47)$ & 0.92 \\
\hline & Group 2 & $45.8 ; 2.87(47)$ & $45.5 ; 4.53(46)$ & 0.585 \\
\hline & Group 3 & $47.03 ; 2.80(47)$ & $45.56 ; 2.56(46)$ & 0.051 \\
\hline
\end{tabular}

In the comparison of the same parameters studied by Riepert et al., ${ }^{[6]}$ Kim et al. ${ }^{[14]}$ Zhang et al., ${ }^{[13]}$ Introna et al., ${ }^{[0]}$ Bidmos et al ${ }^{[8]}$ and our study, morphometric measurements of the males were found to be higher than in females in all of the studies. However, in the study by Zhang et al., ${ }^{[13]}$ morphometric values were found to be smaller than our morphometric data both in males and females. This difference was thought to be related with genetical differences (Table 3). ${ }^{[6,8,9,13,14]}$ Studies found in the literature concluded that the measurements of males were found to be higher

Table 3

Morphometric data of the measurements of calcaneus.

\begin{tabular}{|c|c|c|c|c|c|c|}
\hline & Method & Gender (n) & $a-g$ & $e-f$ & $c-d$ & $a-b$ \\
\hline \multirow[t]{2}{*}{ Present study } & X-ray & Males (66) & 8.55 & 4.9 & 3.9 & 2.53 \\
\hline & & Females (77) & 7.39 & 4.05 & 3.48 & 2.2 \\
\hline \multirow[t]{2}{*}{ Riepert et al. ${ }^{[6]}$} & X-ray & Males (436) & 8.98 & 5.18 & 4.23 & \\
\hline & & Females (364) & 8.2 & 4.67 & 3.78 & \\
\hline \multirow[t]{2}{*}{ Kim et al. ${ }^{[14]}$} & Bones & Males (50) & 8.05 & 4.91 & 3.95 & 2.72 \\
\hline & & Females (54) & 7.37 & 4.46 & 3.55 & 2.49 \\
\hline \multirow[t]{2}{*}{ Zhang et al. ${ }^{[13]}$} & X-ray & Males (148) & 7.19 & & 3.51 & 2.23 \\
\hline & & Females (186) & 6.52 & & 3.12 & 1.96 \\
\hline \multirow[t]{2}{*}{ Campobasso et al ${ }^{[9]}$} & Bones & Males (40) & 7.91 & & & 2.45 \\
\hline & & Females (40) & 7.25 & & & 2.24 \\
\hline \multirow[t]{2}{*}{ Bidmos et al..$^{[12]}$} & Bones & Males (58) & 7.98 & 4.31 & & 2.39 \\
\hline & & Females (58) & 7.36 & 4 & & 2.09 \\
\hline \multirow[t]{2}{*}{ Bidmos et al. ${ }^{[8]}$} & Bones & Males (53) & 8.47 & 4.77 & & 2.29 \\
\hline & & Females (60) & 7.58 & 4.33 & & 2.02 \\
\hline
\end{tabular}


than the females (Table 3). The black community living in Europe had higher calcaneus measurement values than the ones living in Southern African society. Within the framework of this conclusion, according to Bidmos, ${ }^{[15]}$ sex and population cause to a difference in osteometric dimensions of calcaneus.

In the study of Bidmos and Dayal, ${ }^{[16]}$ the values of males' parameters were higher than the females'. The authors further maintained that the results gained by the osteometric methods provided an easy and fast way of determining sex ${ }^{[16]}$ As already asserted in a number of studies. Kim et al., ${ }^{[14]}$ also supported Bidmos and Dayal, ${ }^{[16]}$ claim that males possess higher measurement values as compared to females. ${ }^{[14]}$ On the other hand, while stating that it is difficult to statistically differentiate between white and black Americans by osteometric methods. Steele claimed that these methods could be used to determine sex in the community of Pueblo. ${ }^{[17]}$

\section{Conclusion}

This research shows that the calcaneus plays an important role in the determination of sex. As it was observed that the measurements of length were an easy method for sex determination, the participants' angular measurements did not reveal any statistical differences. In conclusion, if supported by non-metric methods which are mostly used by the forensic anthropologists, radiographic analysis of the calcaneus can be used as an alternative method in the forensic anthropology and the forensic sciences.

\section{References}

1. Cox M, Mays S. Human osteology in archaeology and forensic science. London (UK): Greenwich Medical Media; 2000. p. 548.

2. France DL. Observational and metric analysis of sex in the skeleton. In: Reichs KJ, editor. Forensic osteology: advances in the identification of human remains. 2nd ed. Springfield (IL): Charles C. Thomas; 1998. p. 163-186.
3. Zeyfeoğlu Y. Hancı H. İnsanlarda kimlik tespiti. Sürekli Tıp Eğitimi Dergisi 2001;10:375-7.

4. Washburn SL. Sex differences in the pubic bone. Am J Phys Anthropol 1948;6:199-207.

5. Şahiner Y, Yalçın H. Erkek ve bayanlarda kafatası kemiğinden geometrik morfometri metoduyla cinsiyet tayini ve ramus flexure. Atatürk Üniversitesi Veteriner Bilimleri Dergisi 2007;2:132-40.

6. Riepert T, Drechsler T, Schild H. Nafe B. Mattern R. Estimation of sex on the basis of radiographs of the calcaneus. Forensic Sci Int 1996;77:133-40.

7. Gualdi-Russo E. Sex determination from the talus and calcaneus measurements. Forensic Sci Int 2007;171:151-6.

8. Bidmos MA, Asala SA. Discriminant function sexing of the calcaneus of the South African whites. J Forensic Sci 2003;48:1213-8.

9. Introna F Jr, Di Vella G, Campobasso CP, Dragone M. Sex determination by discriminant analysis of calcanei measurements. J Forensic Sci 1997;42:725-8.

10. Demir A, Çivi S. Assessment of 10-year major osteoporotic and femur fracture risk of postmenopausal women using FRAX ${ }^{\circledR}$. The Turkish Journal of Physical Medicine and Rehabilitation 2014;60:11-8.

11. Saka G, Ceylan A, Ertem M, Palanci Y, Toksöz P. Diyarbakır il merkezinde lise ve üzeri öğrenim görmüş 40 yaş üzeri kadınların menopoz dönemine ait bazı özellikleri ve kalsiyum kaynağı yiyecekleri tüketim sıklıkları. Dicle Tip Dergisi 2005;32:77-83.

12. Bidmos MA, Asala SA. Sexual dimorphism of the calcaneus of South African blacks. J Forensic Sci 2004;49:446-50.

13. Zhang ZH, Chen XG, Li WK, Yang SQ, Deng ZH, Yu JQ, Yang ZG, Huang L. Sex determination by discriminant analysis of calcaneal measurements on the lateral digital radiography. Fa Yi Xue Za Zhi 2008;24:122-5.

14. Kim DI, Kim YS, Lee UY, Han SH. Sex determination from calcaneus in Korean using discriminant analysis. Forensic Sci Int 2013;228:177.e1-7.

15. Bidmos M. Adult stature reconstruction from the calcaneus of South Africans of European descent. J Clin Forensic Med 2006;13:247-52.

16. Bidmos MA, Dayal MR. Sex determination from the talus of South african whites by discriminant function analysis. Am J Forensic Med Pathol 2003;24:322-8.

17. Steele DG. The estimation of sex on the basis of the talus and calcaneus. Am J Phys Anthropol 1976;45:581-8.

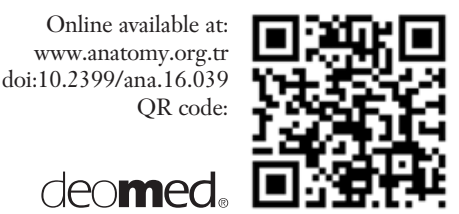

Correspondence to: Muhammet Bora Uzuner, MD Department of Anatomy, School of Medicine, Hacettepe University, Ankara, Turkey Phone: +90 3123052107 e-mail: bora.uzuner@hacettepe.edu.tr

Conflict of interest statement: No conflicts declared.

This is an open access article distributed under the terms of the Creative Commons Attribution-NonCommercial-NoDerivs 3.0 Unported (CC BY-NCND3.0) Licence (http://creativecommons.org/licenses/by-nc-nd/3.0/) which permits unrestricted noncommercial use, distribution, and reproduction in any medium, provided the original work is properly cited. Please cite this article as: Uzuner MB, Geneci F, Ocak M, Bayram P, Sancak İT, Dolgun A, Sargon MF. Sex determination from the radiographic measurements of calcaneus. Anatomy 2016;10(3):200-204. 